KUML 1997-98 


\section{KUML 1997-98 Årbog for Jysk Arkæologisk Selskab}

With summaries in English 
Redaktion: Hans Jorgen Madsen og Jesper Laursen

\section{Omslag: Louise Hilmar}

Tilrettelagning: Narayana Press

Tryk: Narayana Press

Skrift: Bembo 12/13

Papir: $115 \mathrm{~g}$ Arctic Silk

Copyright (C) 1998 by Jysk Arkaologisk Selskab

ISBN 87-7288-597-1

ISSN 0454-6245 


\section{Indhold/Contents}

Hans Jorgen Madsen og Else Roesdahl: Olaf Olsen 70 år $\ldots \ldots \ldots \ldots \ldots \ldots \ldots \ldots$

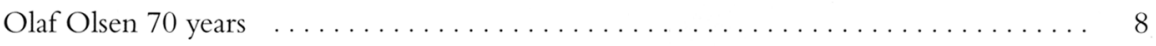

Søren H.Andersen: En mønstret pragtøkse fra ældre Ertebølletid $\ldots \ldots \ldots \ldots \ldots \ldots$.

A Magnificent ornamented axe from the Early

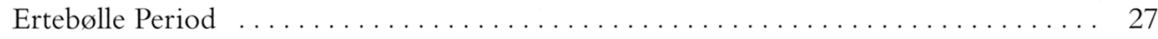

Henrik Skousen: Rønbjerg Strandvolde - en kystboplads

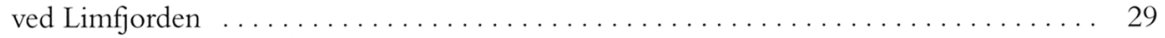

Rønbjerg Strandvolde - a coastal settlement by the Limfjord $\ldots \ldots \ldots \ldots \ldots \ldots \ldots 71$

Lisbeth Christensen: Vandet skole - en ældre romertidsgrav med

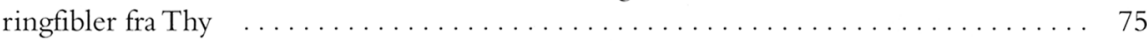

An Early Roman Iron Age grave with ring brooches from

Vandet School in Thy ........................................ 103

Bjarne Henning Nielsen: Jernalderfund fra Egådalen . . . . . . . . . . . . . . . . . 105

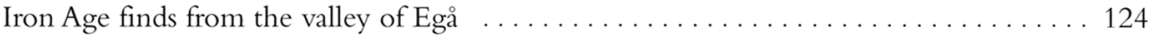

Elisabeth Barfod Carlsen: Et smykke i slægt med guldbrakteaterne $\ldots \ldots \ldots \ldots \ldots \ldots . \ldots 127$

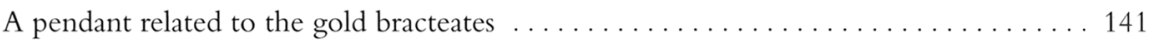

Claus Feveile, Stig Jensen og Kaare Lund Rasmussen: Produktion

af drejet keramik i Ribeområdet i sen yngre germansk jernalder $\ldots \ldots \ldots \ldots \ldots \ldots 143$

The production of thrown pottery in the Ribe area towards

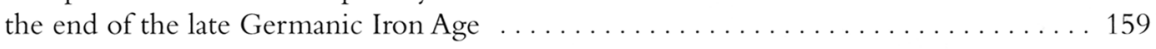

Ole Crumlin-Pedersen: Skibsfundene fra Hedeby $\ldots \ldots \ldots \ldots \ldots \ldots \ldots \ldots$

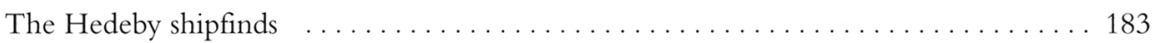

Anne Pedersen: Bidselbeslag fra Bøgeskov Strand . . . . . . . . . . . . . . . . . . . 185

A Harness Cheek-piece from Bøgeskov Strand ....................... 194

Bente Holmberg og Jan Skamby Madsen: Da kom en snekke ... . . . . . . . . . . . . . 197

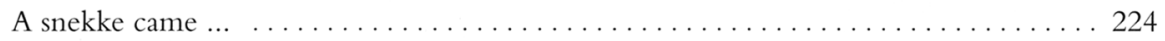

Hans Skov: Udgravningerne i Århus Midtby 1994-97 . . . . . . . . . . . . . . . . 227

The excavations in the centre of Aarhus 1994-97 . . . . . . . . . . . . . . . . . 292

Thomas Bertelsen: Kirketage ........................................ 295

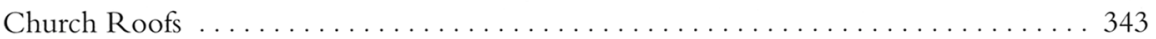

Anmeldelser .................................................. 347

Jysk Arkæologisk Selskab 1997 . . . . . . . . . . . . . . . . . . . . . . . . 369

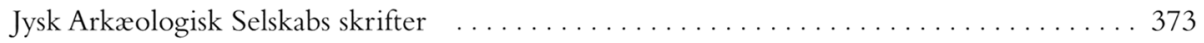




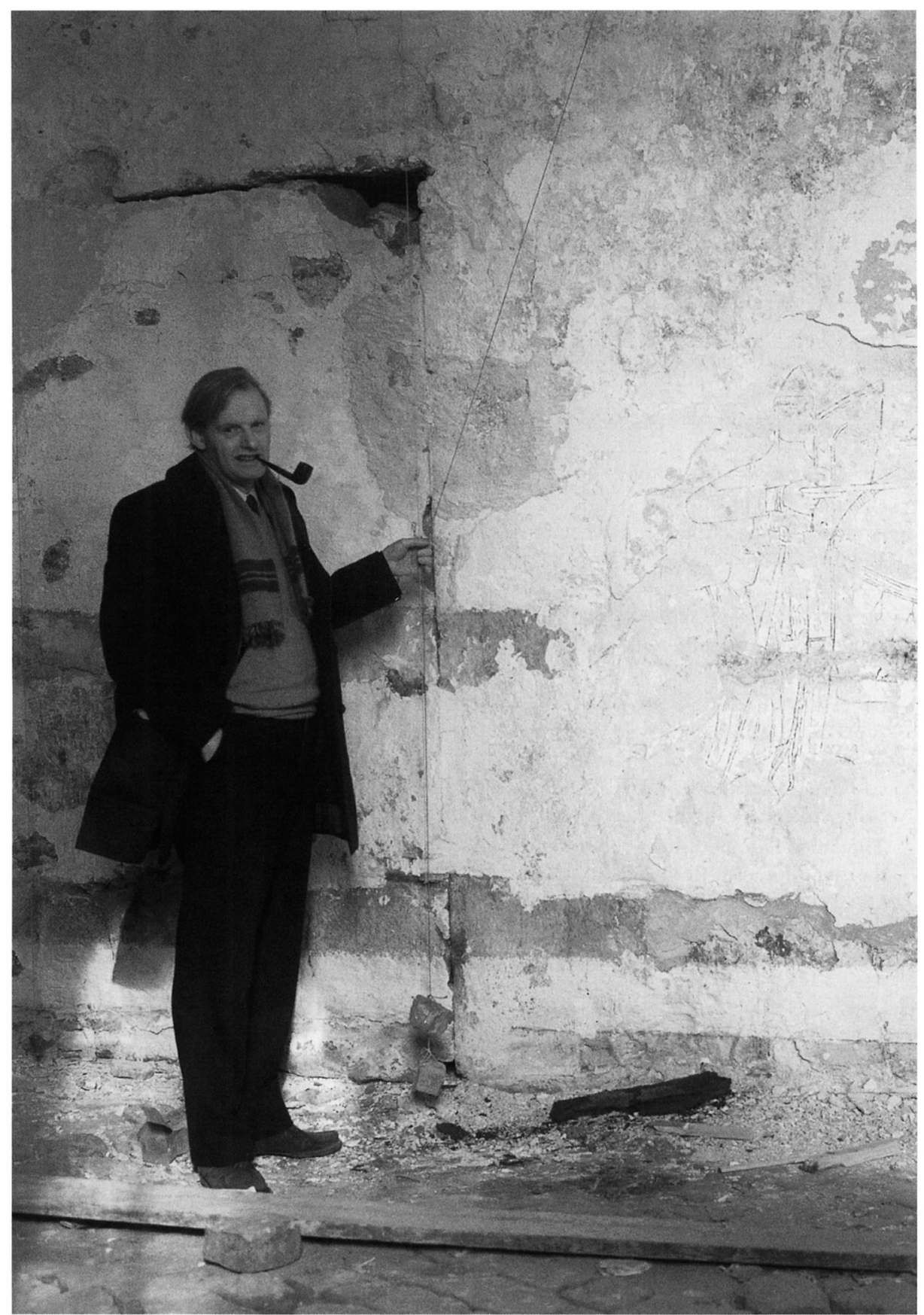

Olaf Olsen på tur med studenterne til nyopdagede kalkmalerier i Lyngby kirke ved Århus. Foto Jens Vellev 1975.

Olaf Olsen on an excursion with students to newly discovered wall-paintings in Lyngby Church near Århus. Photo: Jens Vellev. 


\title{
Olaf Olsen 70 år
}

\author{
Af Hans Jørgen Madsen og Else Roesdahl
}

Den 7. juni 1998 fyldte Olaf Olsen 70 år. I den anledning vil Jysk Arkæologisk Selskab gerne hylde manden, som gennem mange år har spillet en afgørende rolle for arkæologiens vilkår i Danmark og har sat sig markante spor også i Jylland.

Olaf Olsens arkæologiske karriere begyndte i studentertiden med deltagelse i udgravningerne af vikingeborgen Aggersborg. Gennem sit virke som inspektør ved Nationalmuseet havde han jævnligt opgaver i Jylland, hvor især Fyrkatborgen og de mange landsbykirker havde hans store interesse. I 1971 blev han Danmarks første professor i middelalderarkæologi. Det var ved Aarhus Universitet, og han flyttede til Alrø, der har været hans hjemsted lige siden.

I de ti år, han fik på Instituttet på Moesgård, blev faget etableret og udviklet. Han blev en meget inspirerende, igangsættende og afholdt lærer og var en velforberedt og flittig forelæser. Han iværksatte store uddannelsesgravninger, bl.a. på Øm Kloster, og arrangerede ekskursioner til indog udland, bl.a. til England, Grønland, Rusland og Nærorienten. Han tog i disse år også initiativet til det store projekt "Middelalderbyen", der fik vidtrækkende betydning for dansk byarkæologi, og han grundlagde og udbyggede et bibliotek, som i dag regnes for et af de bedste middelalderarkæologiske håndbiblioteker i Europa. Samtidig fik han tid til at skrive et stort værk om Fyrkat.

I 1981 blev Olaf Olsen rigsantikvar og fik igen sin dagligdag i København. Men kontakten til jysk arkæologi blev ikke brudt. Som rigsantikvar var han ansvarlig for alle arkæologiske udgravninger i landet, og det bragte ham i tæet kontakt med landsdelens museer. Desuden var han bl.a. medlem af bestyrelsen for Forhistorisk Museum Moesgård, og han holdt fortsat mange foredrag i foreninger rundt omkring i Jylland. I 1995 trak han sig tilbage fra stillingen som rigsantikvar, men arbejder fortsat med sit fag og en lang række særlige opgaver.

Gennem årene har Olaf Olsen påtaget sig redaktionen af store bogværker på nationalt plan, og det er et karakteristisk træk, at han udtrykker sig på klart og smukt dansk - og forventer det samme af andre. Olaf Olsens virke har altid været båret af en dyb kærlighed til fortidsminderne og en stor omhu for deres ve og vel. Det har også været præget af den overbe- 
visning, at man som forsker har en moralsk pligt til at fortælle bredt om alle de spændende ting, man arbejder med. Alt dette nyder dansk arkæologi stadig glæde af.

\section{Olaf Olsen 70 years}

On the 7th June 1998 Olaf Olsen celebrated his 70th birthday. In honour of the occasion the Archaeological Society of Jutland (Jysk Arkæologisk Selskab) would like to pay tribute to the man who has for many years played a decisive role in Danish archaeology and left a pronounced mark on Jutland, too.

Olaf Olsen began his archaeological career as a student, taking part in the excavations of the Viking fortress of Aggersborg. Through his work as assistant keeper at the Danish National Museum he often had tasks in Jutland; the Viking fortress of Fyrkat and the many medieval village churches here attracted his particular interest. In 1971 he was appointed to Denmark's first chair of medieval archaeology at the University of Aarhus. He moved then to the small island of Alrø, which has been his home ever since.

During his ten years at the Department of Medieval Archaeology at Moesgård he established and developed the subject. He was an inspiring and popular teacher and an always well-prepared and diligent lecturer. $\mathrm{He}$ initiated large-scale training excavations, for instance at the monastery of $\bigcirc \mathrm{m}$, and organised excursions both in Denmark and abroad, to England, Greenland, Russia and the Near East. During these years he also initiated the "The Medieval Town"-project which has been of far-reaching significance for Danish urban archaeology. He founded and developed a library which is today considered to be one of the best medieval archaeology reference libraries in Europe. $\mathrm{He}$ also made the time to publish a major work on the Fyrkat fortress.

In 1981 Olaf Olsen was appointed Keeper of National Antiquities and Director of the National Museum and moved back to
Copenhagen. However, his links with the archaeology of Jutland were not severed. As Keeper of National Antiquities he was responsible for all archaeological excavations in Denmark, and this naturally brought him into close contact with the museums in this part of the country. He was also a member of the Board of Forhistorisk Museum Moesgård and remained $\mathrm{a}$ frequent lecturer at societies throughout Jutland. In 1995 he resigned from the position of Keeper of National Antiquities and Director of the National Museum, but he is still actively engaged in medieval archaeology and undertakes a large number of special assignments.

In the course of the years Olaf Olsen has been general editor of several large works of national importance and one of his characteristics is his ability to express himself in a clear and beautiful language - and to demand the same from others. Olaf Olsen's work has always been founded on a deep love of our ancient monuments and concern for their welfare. In addition, his work has reflected his conviction that a scholar has a moral responsibility to inform the public about all the exciting tasks in which he or she is involved. Danish archaeology is still benefitting from all this.

$$
\begin{array}{r}
\text { Hans Jørgen Madsen } \\
\text { Moesgård Museum } \\
\text { Else Roesdahl } \\
\text { Afdeling for middelalderarkæologi } \\
\text { Aarhus Universitet } \\
\text { Moesgård }
\end{array}
$$
Translated by Annette Lerche Trolle 